\title{
Provider-customer perceptions in service quality: A Gap analysis at Ishik University, Sulaimani
}

\author{
Khayal Mahsum (D), Paveh Muhammed, Ala Omer ${ }^{(D)}$
}

Ishik University,

Sulaimani, Kurdistan Region of Iraq

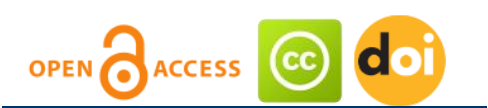

Article history:

Received: September 07, 2019

1st Revision: September

29, 2019

Accepted: November 22, 2019

\section{JEL classification:}

\section{L15}

I21

I25

C55

DOI:

10.14254/jems.2019.4-2.5

\begin{abstract}
It is known that the service quality is the main parameter of every service providing organization to survival. Thus, the organizations must evaluate their service quality periodically and plan for the improvement. While evaluating their service quality, companies shouldn't rely only on the end users but also the gap between what the customers perceives differ from what the providers do. The study aims to compare the service providing perceptions of department/unit managers and the service quality evaluations of students at private universities. To do this, we have used the ServQual survey questionnaire to all service providing academic and administrative units of Tishk International University (Formerly known as Ishik University). The data has been collected in two phases; first is from all managers and the working staff of the academic/administrative unit and the second is from the students for each unit that they receive service from. Those departments were cafeteria, students' affairs, dean of students, academic department of student, and accounting unit. Based on the results, we have given some suggestions to the administration.
\end{abstract}

Keywords: education service quality, ServQual, student satisfaction, Gap analysis.

\section{Introduction}

The service quality in the private institutions is an important issue in the contemporary literature. As the students are the main customers of the private education institutions, student's satisfaction is the key success factor for all universities (Poturak, 2014). From this point of view, a student will be satisfied and be committed to the university in case the services provided by the university is conforming the expectations of the students. Hence, the administration of the universities must first understand the expectations of the students and secondly, confirm $t$ as it is expected. 
According to Parasurman et al., (1985) if perceived service is less than expected, it leads tounsatisfied customer, while it leads to satisfied ones in case conforms or exceeds the expectations. For this reason, it is important for the administration of the private universities to understand the expectations of the students and then conform it ideally.

There is a crucial question comes out here; although the administration understands the expectations of the students, what is the difference between service quality perception of the service providing unit and students. Besides, this difference is considered as one of the main gaps in the service provision (Parasuraman et al., 1988).

There are many private universities in Kurdistan Region of Iraq. Those universities of course focus on the education quality and try to become one of the best universities among all alternatives. Besides, there is a lack of studies which compares the service providing perception of department/unit managers and the students evaluation of service quality. It can be said that closeness of this gap will enhance private universities develop more strategically and evaluate their real service quality level more accurately. From this point of view, this research contains practical and managerial implications.

The study aims to compare the service providing perceptions of department/unit managers and the service quality evaluations of students at private universities. To do this, we have used the ServQual survey questionnaire to all service providing academic and administrative units of Tishk International University (Formerly known as Ishik University). The data has been collected in two phases; first is from all managers and the working staff of the academic/administrative unit and the second is from the students for each unit that they receive service from. Those departments were cafeteria, students' affairs, dean of students, academic department of student, and accounting unit. The results have been analyzed descriptively. The perceptions of managers have been subtracted from the perceptions of the students. The closer result to zero means better conformation of the perceptions.

\section{Literature review}

\subsection{Service quality}

Service Quality is a framework which can help one understand the reasons of customer satisfaction (Aydinli \& Demir, 2015). Moreover, perceived service quality can be defined as the customer's judgment about superiority or excellent of a product (Zeithmal,1988). Service quality is measure as how well an actual service delivery matches with customer expectations. Delivering quality service means conforming to customer expectations on a consistent basis (Torlak, Demir \& Budur, 2019).

"Quality" in a service organization can be defined as meeting customer's expectations with what actually is served (Demir, Talaat \& Aydinli, 2015). The nature of most services is such that the customer is present in the delivery process. This means that the perception of quality is influenced not only by the "service outcome" but also by the "service process" (Demir \& Eray, 2015). The "perceived quality" lies along a continuum (Demir \& Mukhlis, 2017). "Unacceptable quality" lies at one end of this continuum, while "ideal quality" lies at the other end. The points in between represent different gradations of quality. Lewis and Booms ,1983; Lethtinen \& Lethtinen1982;Gronroos ,1984; Parasurman, Zeithaml \& Berry 1985). It is important to evaluate the service quality because it is a measure of whether the service delivered matches customer expectation (Lewis \& Booms 1093).

Service quality is key tool to achieve customer's satisfaction. Varying behaviors and attitudes of customers demand high service quality to attain their positive perception of service quality. Service quality has linear and positive relationship with success and profitability of business Ladhari et al., (2011)

As service quality improves, the chances of customer satisfaction increases. In turn, perceptions of better service value in service exchanges provided by service organizations leads to increased customer satisfaction (Arasli, Mehtap-Smadi, \& Turan Katircioglu, 2005; Lovelock \& Wirtz, 2007).

\subsection{Service quality in higher education institution}

Numerous researches has been studied on service quality in higher education. For example, Hill (1995) exploratory study which has monitored a group of students' expectations and perceptions of service quality over time, which is not stable over a time and the reason of this instability was out of the scope. 
Sulan and Wong (2010) have found five critical research agenda in the field of service quality in higher education sector as follow;

(1) The role of importance, expectation and performance on service quality in higher education.

(2) The critical service attributes and dimensions of service quality in higher education.

(3) The critical antecedents of service quality in higher education.

(4) The effectiveness of ECSI methodology in higher education.

(5) The quest for an effective model in higher education.

Kajenthiran and Karunanithy (2015), focused on the relationship and the impact between the determination of service quality and student's satisfaction, the result of the study show that service quality in private higher education institution in Jaffana positively associated with student's satisfaction .

Ali and Mohammed (2014) investigated the research to assess relationship between service quality and student's satisfaction, study found that positive significant relationship between service quality and students satisfaction.

Abu Hasan et al., (2008) suggested that service quality has significant positive relationship with student satisfaction. Further, by improving service quality, it may potentially improve the students' satisfaction.

Kamal and Ramzi (2002) attempted to measure the students attitude of registration and academic advising across different faculties to assure positive quality service, as a result, students portrayed that registration process is one of the process that make students frustrate in particular with regard time taken to complete registration .

Cardona and Bravo (2012) suggested that the service quality was the most important element which influence students' satisfaction positively. However, it fosters the commitment of students toward their universities.

Hossain and Howdhury (2018) developed a model that tests the determinants which impact the success of students in higher education. Moreover, they have suggested that: 'curriculum quality', 'teaching competence', 'service facility', and 'service delivery' provided by a private university are positively related to 'perceived value', while students' perceived satisfaction is dependent on 'service facility'.

Osman and Saputra (2019), investigate the relationship between service quality, program quality, institutional image and student satisfaction in the context of higher education. The study also attempted to describe the mediating impact of institutional image between service quality, program quality and student satisfaction. Result confirmed the direct relationship between of service quality and student satisfaction. Therefore, a deficiency of indirect relationship has emerged between service quality and student satisfaction in the circumstance of higher education. This investigation has emphasized the role of service quality and program quality as the two independent variables that have a relationship on the dependent variable, that is, student satisfaction.

Brenda and Baron (2000) studied the student perception of service quality in higher education, students suggests that students' perceived service quality has three dimensions: "requisite elements", which are essential to enable students to fulfill their study obligations; "acceptable elements", which are desirable but not essential to students; and "functional elements", which are of a practical or utilitarian nature. Student evaluation of certain aspects of service quality may change resulting from student experience.

Jusohet al., (2004) claimed that seniority have a significant effect on the perception of service quality, the higher grades they are the more expectation they have for university. However, Anim and Mensah (2015) stated that students in private institutions are more informed than students in public institutions, further students' expectations in private institutions are higher and the quality service perceived is greater than the students in public institutions.

Ada, Baysal and Erkan (2017) claimed that students perception of service quality in higher education institution show a significant differences according to the year of university establishment, physical facilities, diplomas gained by university, and study show that females students show a higher evaluation to the service quality than the male students in spite of academic position and university image. Besides, Voss, Gruber and Szmigin (2007) investigated what students' needs were during their education. The result have revealed that students prefer their lecturer be knowledgeable, enthusiastic, approachable, and friendly, and the academic interest of students encourage them less than the vocational aspect of their study. Along with this study, Cardona and Bravo (2012) investigated the service quality factor that impact student's satisfaction. The study show that showed significant variables in explaining student satisfaction as: trust developed toward the university and the academic program, and the perception they have of assessment techniques as a challenge to improve intellectual growth. Finally, Green (2014) has 
elaborated the service quality in higher education. The study revealed that on average customer have higher expectation in tangibles, reliability and assurance. Further, there is very few study which has investigated the service quality in higher education in every department and unit simultaneously. Only Demir (2017) has studied the impact of ServQual determinants on the students satisfaction in every unit and department at Ishik University, Kurdistan Region of Iraq. Further, Demir and Guven (2017) have studied the impact of ISO quality management systems on the students' satisfaction at the same university.

There is no study which has investigated the perceptions between service providers and the customers of the services in higher educations. In this study, we have evaluated the perceptions of managers each department/unit and the students who receive services of the concerning department/unit.

For the measurement of service quality, the SERVQUAL instrument is considered to have a wide applicability Berry et al., 1985; Johnston and Lyth, 1991; Sasser et al., 1978. Parasuraman et al. (1985) provided a list of ten determinants of service quality as a result of their focus group studies with service providers and customers: access, communication, competence, courtesy, credibility, reliability, responsiveness, security, understanding and tangibles. Further. Berry et al., (1985) they added that "although the relative importance of the categories would vary from one service industry to the next, we believe the determinants of service quality in most (if not all) consumer service industries are included in this list".

In 1988, Parasuraman et al., have decreased the determinants of service quality to five as empathy, responsiveness, assurance, reliability, and tangibles.

Tangibles at higher education means physical facilities, equipment, and appearance of university personnel. It is the appearance of the physical facilities, equipment, personnel and communication materials (Demir \& Guven, 2017) In simple words, tangibles are about creating foremost impressions. All organizations desire that their consumers get an exceptional and positive foremost impression. Focusing on this particular dimension will help them to gain maximum benefit (Swar \& Sahoo, 2012). Based on the tangibles, universities should utilize state of art technologies in the classes, laboratories, and staff offices. Moreover, university buildings and facilities must be modern, clean and neat. However, the academic and administrative staff must be wearing and seeming modern, clean, and neat (Demir, 2017). Another dimension of the service quality is reliability.

Reliability is the ability to perform the promised service dependably and accurately the first time (Demir, Eray \& Erguvan, 2015). It is the ability to deliver the promised service precisely and consistently. Crosby (1992, p.36) estimates that the cost of not doing things right the first time for a typical service organization is equal to around $40 \%$ of the total operating costs. Total quality management in human service organizations Lawrence L. Martin The association between dimensions of service quality and customer satisfaction was investigated by Ibáñez et al. (2006). They found a significant relationship between reliability of services on the satisfaction level of customers. The literature reveals an increased degree of positive relationship between service quality, customer satisfaction and performance (both financial and non-financial) where face-toface dealing between customer and employee is the only focus (Muyeed, 2012).

Another dimension of the service quality is responsiveness. In education, It is the willingness to help student and provide prompt advice and service), provide timely service and eagerness to help the customers, the ability to deal effectively with complaints and promptness of the service. Ghobadian, A., Speller, S., \& Jones, M. (1994). (Sedigheh, 2015). Responsiveness to customers is considered an important predictor of service quality (Mittal \& Lassar, 1996), and driver of customer satisfaction (Andaleeb \& Basu, 1994; Handfield and Bechtel, 2002; Tiedemann et al. 2009)

Assurance is another important element of service quality. In education, it can be defined as the ability of university to demonstrate competence, confidence, courtesy, credibility and security. Knowledgeable and politeness of employees and their skills to inspire trust and confidence. In addition to tangibles, reliability and responsiveness; assurance has been identified as a significant dimension of service quality by Parasuraman et al. (1988). They propose that all of these dimensions significantly enhance customer satisfaction. It is believed that if the employees of financial institutions display trustworthy behavior, the satisfaction level of customers can be enhanced significantly. It may also positively influence repurchase intension of customers (Ndubisi, 2006; and Ndubisi \& Wah, 2005).

Empathy is the fifth element of service quality. In education, it can be defined as the ability to care and provide individualized attention to students. Individual attention and caring of the customers (Parasurman et al., 1988). However, a positive and significant relationship is found between empathy and customer satisfaction by Iglesias and Guillén (2004). It was proposed in another research study, that customers may remain unsatisfied with service quality if a gap is left in 
empathy by Al-Marri et al. (2007). Customer satisfaction is significantly impacted by empathy. It makes customers contended and in the long-run serves as an important predictor in improving the financial performance of the organization. Wieseke et al. (2012) empirically investigated the role of empathy in service quality and its impact on customer satisfaction. It was established that customers treated emphatically are more often visitors and prone forgive any mistakes that may occur. Empathy creates an emotional relationship with customer, providing customer a touch of importance for business. This leads to retention and creation of new customer's pool. Juneja (2011) has also studied the correlation between service quality dimensions and customer satisfaction in Bangladesh banking industry. It was found that customer loyalty can be won through empathy. Empathy can play role in improvement of service quality, customer loyalty and finally satisfaction Karatepe (2011) explored the service environment impact with empathy and reliability on loyalty. Empathy works as a moderator between quality and customer satisfaction. Empathy can change the behavior of customer ultimately.

Considering these dimensions of quality, service quality is determined as the difference between student expectations and perceptions of service delivery quality. In general, Consumers are dissatisfied only if the experienced quality is worse than expected (Parasurman, et al., 1988).

\subsection{Customer satisfaction}

Kotler (2000) defined satisfaction as: “a person's feelings of pleasure or disappointment resulting from an evaluation process comparing a product's perceived performance (or outcome) in relation to his or her expectations" i.e.: when the consumer of a good or service compares what is received against what is expected from the utilization of that good or service. Hoyer and MacInnis (2001) said that satisfaction can be associated with feelings of acceptance, happiness, relief, excitement, and delight (Demir, 2019).

Customer satisfaction is the result of a comparison between customer purchase of the expected performance with actual performance and perceived and payment expenses (Taghizadeh, 2012). Customer satisfaction is a physical concept that is due personal comparison from understanding of product performance with the experience obtained of the performance (Chu, 2002).

There are many factors that affect customer satisfaction. According to Hokanson (1995), these factors include friendly employees, courteous employees, knowledgeable employees, helpful employees, accuracy of billing, billing timeliness, competitive pricing, service quality, good value, billing clarity and quick service.

In order to achieve customer satisfaction, organizations must be able to satisfy their customers needs and wants (La Barbera \& Mazursky, 1983). Customers' needs state the felt deprivation of a customer (Kotler, 2000). Whereas customers' wants, according to Kotler (2000) refer to "the form taken by human needs as they are shaped by culture and individual personality"

Satisfaction is the condition that is obtained after use of the product or service for the customer. Satisfaction is process understand and evaluate of customer from experiencing product consumption by using service. Literature review suggests that Satisfaction is achieved as a result of two parallel processes that include: emotional process and normative process (Robinot \& Giannelloni, 2010; Abdulla, Wirya \& Top, 2019).

Although satisfaction and service quality have a common feature but satisfaction has the broader concept than quality generally, because focuses on services dimensions. The service quality is considered as part of satisfaction. Service quality represents a customer's perception from five dimensions of service, while satisfaction is more pervasive and including quality of service, product quality, price and also situational factors and personal factors (Javadin, 2009).'

Many researchers have looked into the importance of customer satisfaction, Customer satisfaction is something beyond a positive impact on efforts done in the organization. This not only makes the activity staff, but is considered a source of profit for the company. Customer satisfaction provides many benefits for companies and higher levels of customer satisfaction leads to loyalty.

\section{Methodology}

\subsection{Data collection and sample description}

Data has been collected from Tishk International University (formerly known as Ishik University), Sulaimani, Kurdistan region of Iraq. The gap analysis was important at the university for the following reasons: 
a) The managers have been thinking that they were delivering a good service to the students but not aware of the gap between service providers (themselves) and receiver (students)

b) results of gap analysis would provide such an information to the managers that they would see from which points there were more gaps so that they could prioritize more gaps strategically.

Tishk International University has established a new campus in Sulaimani, Kurdistan Region of Iraq since 2015 and the campus needs further managerial improvements from the service quality point of view. The campus has around 200 students by 2019. The survey questionnaire has been conducted to the students who has been willing to fill the survey. Each service quality questionnaire was conducted to 120 students on average so that as a result ( 7 units/departments $\mathrm{X}$ 120 students) above 800 data has been obtained in total from students. However, managers and employees from each department has fulfilled the same service quality survey for the gap analysis. Approximately 20 data has been obtained in total from the departments/units.

\subsubsection{Survey group (managers and employees)}

Managers are the people who are primarily responsible from the quality of service at every organization. Further, division managers are responsible from the service quality of primarily of their own department. Thus, their perceptions of service delivery quality would be very important. Secondly, employees are the people who follow the rules and regulations which have been determined by their managers and deliver the service with their motivation. So that the perceptions of those two administrative parts are important to understand. Thus, we have conducted the survey, which has been conducted to the students, to the managers and employees of each unit as well. The difference was, we have changes phrases from service receiving to service delivery. Please see appendix.

\subsubsection{Survey group (Students)}

Students are the main internal customers who receive services from various units/departments of the university. However, they pay for those services and their perception of service quality are very important and main variable to improve quality. Therefore, we have conducted the service quality survey as the party which receives services from each unit/department. Please see appendix.

\subsection{Measures}

When it says service quality, ServQual of Parasuraman et al. (1988) is undeniably important. The concerning questionnaire has been used in a very wide range of studies in service providing field. Hence, we have used the same variables in this study as well. The questionnaire contained six variables such as empathy, responsiveness, assurance, reliability, tangibles, and customer satisfaction. The study aims to evaluate the gap between service providers' and customers' perceptions about the service quality at each department/unit of the university. To do this, the questionnaire has been conducted to the students who are utilizing various services in the university. For example, the students, who have been utilizing the cafeteria services, have filled the survey questionnaire about service quality of cafeteria. All the units and departments has been evaluated through this way.

Likert scale has been used whereas 1 means strongly disagree and 5 means strongly agree. The meanings of the scale has been explained to the participants before they started filling it.

\subsection{Data analysis and findings}

In this section, we have analyzed the data that has been gathered from the students. They have evaluated the level of empathy, responsiveness, assurance, reliability, and tangibles at each unit/department of the university along with the satisfaction. Business management, civil engineering, and architectural engineering departments are the academic departments where the students are receiving private education from. Further, accounting, dean of students, students' affairs, and cafeteria are the administrative units where students receive financial, social-culturalsports, official, and nutrition services respectively. Besides, the managers and employees of the concerning units/departments have evaluated their service providing quality. The differences by students' perceptions - staff perceptions indicate the gap between students' and administration's perceptions. The results those are minus indicate that staff perceptions are above the students 
perceptions. Besides, if the results are positive, staff perceptions are below the students' perceptions. Please see the Table 1 for the further details.

Table 1: Comparison results of student-staff perceptions of service quality

\begin{tabular}{|c|c|c|c|c|c|c|c|c|}
\hline \multirow[b]{2}{*}{ Dimensions } & \multirow[b]{2}{*}{ Unit/Department } & \multicolumn{3}{|c|}{ Staff Perceptions } & \multicolumn{3}{|c|}{ Student Perceptions } & \multirow[t]{2}{*}{ Difference } \\
\hline & & $\mathrm{N}$ & Mean & $\begin{array}{c}\text { Std. } \\
\text { Deviation }\end{array}$ & $\mathrm{N}$ & Mean & $\begin{array}{c}\text { Std. } \\
\text { Deviation }\end{array}$ & \\
\hline \multirow{8}{*}{ Empathy } & business management & 2 & 3.58 & 0.12 & 35 & 3.41 & 1.01 & -0.17 \\
\hline & civil engineering & 3 & 3.39 & 0.35 & 31 & 3.38 & 1.13 & -0.01 \\
\hline & architectural & 6 & 4.53 & 0.49 & 68 & 3.94 & 0.99 & -0.59 \\
\hline & engineering & & & & & & & \\
\hline & accounting & 2 & 3.75 & 0.35 & 124 & 3.14 & 1.23 & -0.61 \\
\hline & dean of students & 1 & 5.00 & & 114 & 3.22 & 1.10 & -1.78 \\
\hline & students affairs & 3 & 3.78 & 0.79 & 85 & 4.83 & 1.62 & 1.05 \\
\hline & cafeteria & 1 & 4.00 & & 114 & 3.92 & 1.02 & -0.08 \\
\hline \multirow{7}{*}{ Responsiveness } & business management & 2 & 4.20 & 0.28 & 35 & 3.37 & 1.00 & -0.83 \\
\hline & civil engineering & 3 & 4.13 & 0.23 & 30 & 3.07 & 1.23 & -1.06 \\
\hline & architectural & 6 & 4.53 & 0.50 & 68 & 3.88 & 1.03 & -0.65 \\
\hline & engineering & & & & & & & \\
\hline & accounting & 2 & 3.80 & 0.85 & 124 & 3.12 & 1.27 & -0.68 \\
\hline & dean of students & 1 & 5.00 & & 115 & 3.11 & 1.03 & -1.89 \\
\hline & students affairs & 3 & 3.60 & 0.72 & 85 & 4.73 & 1.65 & 1.13 \\
\hline \multirow{7}{*}{ Assurance } & business management & 2 & 4.17 & 1.18 & 35 & 3.21 & 1.24 & -0.96 \\
\hline & civil engineering & 3 & 4.22 & 0.51 & 31 & 3.13 & 1.23 & -1.09 \\
\hline & $\begin{array}{l}\text { architectural } \\
\text { engineering }\end{array}$ & 6 & 4.22 & 0.66 & 68 & 3.98 & 0.99 & -0.24 \\
\hline & accounting & 2 & 4.00 & 0.00 & 124 & 3.27 & 1.25 & -0.73 \\
\hline & dean of students & 1 & 4.67 & & 113 & 3.23 & 1.05 & -1.44 \\
\hline & students affairs & 3 & 3.56 & 0.51 & 85 & 4.73 & 1.62 & 1.17 \\
\hline & cafeteria & 1 & 4.00 & & 114 & 3.19 & 1.11 & -0.81 \\
\hline \multirow{7}{*}{ Reliability } & business management & 2 & 3.75 & 0.00 & 34 & 3.26 & 1.08 & -0.49 \\
\hline & civil engineering & 3 & 3.17 & 0.76 & 31 & 2.79 & 1.03 & -0.38 \\
\hline & architectural & 6 & 3.21 & 1.46 & 68 & 3.86 & 1.02 & 0.65 \\
\hline & $\begin{array}{l}\text { engineering } \\
\text { accounting }\end{array}$ & 2 & 3.50 & 1.06 & 124 & 3.14 & 1.23 & -0.36 \\
\hline & dean of students & 1 & 4.75 & & 115 & 3.15 & 1.06 & -1.60 \\
\hline & students affairs & 3 & 3.22 & 0.38 & 85 & 4.74 & 1.63 & 1.52 \\
\hline & cafeteria & 1 & 2.75 & & 114 & 3.21 & 1.04 & 0.46 \\
\hline \multirow{7}{*}{ Tangibles } & business management & 2 & 3.33 & 0.00 & 34 & 3.27 & 1.06 & -0.06 \\
\hline & civil engineering & 3 & 3.00 & 0.87 & 30 & 3.43 & 1.01 & 0.43 \\
\hline & architectural & 6 & 4.22 & 0.83 & 68 & 3.90 & 1.09 & -0.33 \\
\hline & $\begin{array}{l}\text { engineering } \\
\text { accounting }\end{array}$ & 2 & 3.50 & 0.00 & 124 & 3.34 & 1.31 & -0.16 \\
\hline & dean of students & 1 & 4.00 & & 112 & 3.21 & 1.02 & -0.79 \\
\hline & students affairs & 3 & 3.17 & 0.50 & 85 & 5.06 & 1.79 & 1.90 \\
\hline & cafeteria & 1 & 3.83 & & 114 & 3.24 & 0.99 & -0.60 \\
\hline \multirow{8}{*}{ Satisfaction } & business management & 2 & 3.67 & 0.47 & 30 & 3.29 & 1.27 & -0.37 \\
\hline & civil engineering & 3 & 2.67 & 0.88 & 31 & 2.92 & 1.27 & 0.26 \\
\hline & architectural & 6 & 4.17 & 0.55 & 68 & 3.98 & 1.11 & -0.19 \\
\hline & engineering & & & & & & & \\
\hline & accounting & 2 & 3.33 & 0.47 & 123 & 3.22 & 1.35 & -0.11 \\
\hline & dean of students & 1 & 4.00 & & 115 & 3.13 & 1.07 & -0.87 \\
\hline & students affairs & 3 & 3.56 & 0.96 & 85 & 4.89 & 1.64 & 1.33 \\
\hline & cafeteria & 1 & 3.67 & & 113 & 3.27 & 1.13 & -0.40 \\
\hline
\end{tabular}

Given in the Table 1, students evaluated students' affairs unit's (4.83) and architectural engineering department's (3.94) empathy level toward students as good. Besides, dean of students (3.22) and accounting (3.14) units showed relatively low empathy to the students. When the differences between the students and staff investigated, it has been observed that staff perceptions in civil engineering (3.39) and business management (3.58) departments and cafeteria (4.00) have been closest to the students' evaluations in both departments' empathy dimension. Besides, dean of students (5.00) had highly above perceptions that what the students actually perceived (3.22) about the empathy of the concerning unit. As a result, the biggest difference between students' and staff evaluations has occurred in this units $(-1.78)$. On the other hand, administration of the students' affairs had the biggest positive gap whereas the students' perceptions have been above the perceptions of staff (1.05). 
As responsiveness is willingness to solve the problems of the students, students' affairs has been the top department which shows responsiveness to the students in problem solving (4.73). Besides, civil engineering (3.07), accounting (3.12), and dean of students (3.11) were the lowest achieving units/departments. When the perceptions of students have been subtracted from the perceptions of staff, it has been revealed that the biggest negative gap was in deans of students unit $(-1.89)$. Besides, students' affairs unit had the biggest positive gap (1.13) as the students perceive more than what the students affairs show responsiveness.

Assurance in the education has been evaluated as the knowledge about what a unit or department is performing. Given in the Table 1, it has been observed that the students' affairs (4.73) and architectural engineering (3.98) had the highest assurance in perceptions of the students. On the other hand, business management (3.21), civil engineering (3.13), dean of students (3.23), and cafeteria (3.19) had the relatively low in assurance dimension. Evaluating the gap between students and staff perceptions, dean of students $(-1.44)$ and civil engineering $(-1.09)$ had the biggest negative gap while the biggest positive gap was at students affairs (1.17). The results reveal that the biggest gap between students and the staff have occurred in this point.

Reliability is doing it right and continuously while providing a service. Given in the Table 1, the study showed that with the value of 4.74, students' affairs unit had the highest evaluation results while civil engineering had dramatically low (2.79). The gap evaluation results show that dean of students $(-1.6)$ had the biggest negative gap between student and staff evaluation. Besides, students' affairs (1.52) had the biggest positive gap.

Tangibles explain the technology and equipment the department or unit utilizing, how neat and modern the visually of the academic and the administrative staff are. Given in the Table 1 above, the tangibles in the students' affairs (4.9) had the highest perception value in this point. On the other hand, dean of students (3.21) and the business management (3.27) were the relatively low than others. The gaps between students and the staff evaluations show that the departments and the units are relatively close to the students evaluations whereas they are aware the lacking tangibles in the campus. On the other hand, students' affairs had the biggest positive gap between students and the staff (1.9).

Satisfaction is a main determinant which retains the customers and make them loyal to a brand. The results those have been revealed from the Table 1 show that students affairs (4.89) was the department which the students have been satisfied the most. Besides, civil engineering (2.92) was the department which the students dramatically was less satisfied than the other departments. When the gap analysis has been proposed, it has been revealed that dean of the students $(-0.87)$ had the biggest negative gap between students and staff while students' affairs (1.33) had the biggest positive gap. Overall the satisfaction of the students in units and departments have been as average around three.

\section{Conclusion}

The study aimed to investigate the gap between the service quality perceptions between the staff and the students at private institutions. It is known that the service quality is the main parameter of every service providing organization to survival. Thus, the organizations must evaluate their service quality periodically and plan for the improvement. While evaluating their service quality, companies shouldn't rely only on the end users but also the gap between what the customers perceive differ from what the providers do.

In this research we have asked questions to unit/department employees and managers as service providers and students as service receivers at a private university. The services of all units/departments have been evaluated by the students and the service providers of those units/departments. The results have been subtracted from each other and the gap has been determined.

The initial results have shown us that the service quality of the students' affairs in the university is highly appreciated by the students. The staff of the unit shows good level of empathy, responsiveness, assurance, reliability, and tangibles to the students. Therefore, students are highly satisfied with that administrative unit. Besides, the employees and the managers of the unit are not aware of what they are providing to the students. This situation might be considered as a problem for the unit. Service quality must be known by the unit and they must be aware of their strengths and weaknesses for the future plans. Thus, the results must be shared with the managers and the employees of the students' affairs and they must know about evaluation results of the students and act accordingly. They must keep what they are doing well and even develop it.

Second important result of the research was about the dean of students in the university. Based on the analysis results, students satisfaction with the dean of students was average and close to dissatisfaction. Besides, the administration of the department evaluated their service quality and 
the student satisfaction as very high. This case is a big danger for a department while indicating their strengths and weaknesses of the unit/department. It has been determined that the gap between what the students evaluate and what the department administration thinks are very different from each other. Thus, the administration must reevaluate what they need to analyze and plan for the further improvement of service quality in the unit.

The third important result of the research was about the service quality in civil engineering department. Students evaluated the service quality of the department as weak overall. Besides, the administration also is aware of the situation. Although the weakness is a problem for the future of the department, it is a strength that the administration and the employees are aware of what they are providing for the students. Through this way, the department can use this potential and make a good plan for the future in order to develop the service quality of the department.

The research has some managerial implications. By this methodology, the management may see how the service receivers perceive the service quality of a unit or department. This make an organization to evaluate their service quality comprehensively. Secondly, they can see the gap between what the managers and employees think they are providing to the customers, and what actually the customers perceive. Through this way, the management can make better plan for the further developments of the service quality unit/department based.

Research has some limitations. Firstly, the research has been studied in one campus of Tishk International University (formerly known as Ishik University) and cannot be generalized to whole private institutions in the region. Secondly, the study contains only around 124 data for each department and must be increased in the future researches.

\section{Appendix A. Supplementary material}

Supplementary data associated with this article can be found, in the online version, at https://doi.org/10.14254/jems.2019.4-2.5

\section{Funding}

The authors received no direct funding for this research.

\section{Citation information}

Mahsum, K., Muhammed, P., \& Omer, A. (2019). Provider-customer perceptions in service quality: A Gap analysis at Ishik University, Sulaimani. Economics, Management and Sustainability, 4(2), 49-60. doi:10.14254/jems.2019.4-2.5.

\section{References}

Abouchedid, K., \& Nasser, R. (2002). Assuring quality service in higher education: registration and advising attitudes in a private university in Lebanon. Quality Assurance in Education, 10(4), 198-206.

Abdulla, N., Wirya, H., Top, C. (2019). Service quality among Kurdistan hotels. International Journal of Economics, Commerce and Management, 7(6) 717-723

Ada, S., Baysal, Z. N., \& Erkan, S. S. S. (2017). An evaluation of service quality in higher education: Marmara and Nigde Omer Halisdemir universities' department of education students. Universal Journal of Educational Research, 5(11), 2056-2065.

Andaleeb, S. S., \& Basu, A. K. (1994). Technical complexity and consumer knowledge as moderators of service quality evaluation in the automobile service industry. Journal of Retailing, 70(4), 367-381.

Anim, S. K., \& Mensah, J. (2015). Service quality in higher education: A comparative study in tertiary institutions in Sub Saharan Africa. Global Journal of Educational Studies, 1(2), 24-44.

Arasli, H., Mehtap-Smadi, S., \& Turan Katircioglu, S. (2005). Customer service quality in the Greek Cypriot banking industry. Managing Service Quality: An International Journal, 15(1), 41-56.

Aydinli, C., \& Demir, A. (2015). Impact of non-technical dimensions of service quality on the satisfaction, loyalty, and the willingness to pay more: a cross-national research on GSM operators. International Journal of Economics, Commerce and Management, 3(11), 1-16.

Cardona, M. M., \& Bravo, J. J. (2012). Service quality perceptions in higher education institutions: the case of a Colombian university. Estudios gerenciales, 28(125), 23-29. 
Chu, T. C., \& Lin, Y. C. (2002). Improved extensions of the TOPSIS for group decision making under fuzzy environment. Journal of Information and Optimization Sciences, 23, 273-286

Demir, A. (2017). Importance of data analysis on achieving the organizational goals during the short term strategic plan: Case of service quality and students' satisfaction level at Ishik University. International Journal of Social Sciences and Educational Studies, 3(3), 110-121.

Demir, A. (2019). The impact of strategic operations management decisions on shoppers' wellbeing. Asian Academy of Management Journal, 24(1), 25-57.

Demir, A., \& Aydinli, C. (2016). Exploring the quality dimensions of mobile instant messaging applications and effects of them on customer satisfaction. International Journal of Computer Theory and Applications, 9(22), 1-15.

Demir, A., \& Eray, O. (2015). Effect of non-technical dimensions of service quality on "satisfaction", "loyalty", and "willingness to pay more" of the customers: the case of Georgian internet service providing companies.Journal of Research in Business, Economics and Management, 5(1), 500-508.

Demir, A., \& Guven, S. (2017). The influence of ISO certificate on quality evaluation of students: a case study at Ishik University. Advances in Social Sciences Research Journal, 4(3).

Demir, A., \& Mukhlis, M. (2017). An evaluation of gated communities as a product: An empirical study in Sulaimaniyah, Iraq. Theoretical and Empirical Researches in Urban Management, 12(3), 63-84.

Demir, A., (2019). A Benchmarking of service quality in telecommunication services: Case study in Kurdistan Region of Iraq. International Journal of Social Sciences and Educational Studies, 5 (3), 216-231

Demir, A., Eray, O., \& Erguvan, M. M. (2015). How non-technical dimensions of service quality effects satisfaction and loyalty of customers at GSM service sector in Georgia. International Journal of Engineering Technology and Scientific Innovation, 1(02), 150-162.

Demir, A., Talaat, K., \& Aydinli, C. (2015). The relations among dimensions of service quality, satisfaction, loyalty, and willingness to pay more: case of GSM operators service at NorthernIraq. International Journal of Academic Research in Accounting, Finance and Management Sciences, 5(4), 146-154.

Ganguli, S., \& Roy, S. K. (2011). Generic technology-based service quality dimensions in banking: Impact on customer satisfaction and loyalty. International journal of bank marketing, 29(2), 168-189.

Ghobadian, A., Speller, S., \& Jones, M. (1994). Service quality: concepts and models. International journal of quality \& reliability management, 11(9), 43-66.

Green, P. (2014). Measuring service quality in higher education: A South African case study.

Grönroos, C. (1982). An applied service marketing theory. European journal of marketing, 16(7), 3041.

Grönroos, C. (1984). A service quality model and its marketing implications. European Journal of marketing, 18(4), 36-44.

Handfield, R. B., \& Bechtel, C. (2002). The role of trust and relationship structure in improving supply chain responsiveness. Industrial marketing management, 31(4), 367-382.

Hasan, H. F. A., Ilias, A., Rahman, R. A., \& Razak, M. Z. A. (2008). Service quality and student satisfaction: A case study at private higher education institutions. International Business Research, 1(3), 163-175.

Hill, F. M. (1995). Managing service quality in higher education: the role of the student as primary consumer. Quality assurance in education, 3(3), 10-21.

Hokanson, S. (1995). The deeper you analyze, the more you satisfy customers. Marketing News, 29(1), 16-16.

Hossain, M. A., Hossain, M. M., \& Chowdhury, T. H. (2018). Understanding the success of private universities: An empirical investigation from graduates' perspective. International Journal of Quality \& Reliability Management, 35(1), 145-162. 
Hoyer, W. D., \& MacInnis, D. J. (2001). Consumer Behaviour. 2nd ed., Boston, Houghton Mifflin Company.

Ibáñez, V. A., Hartmann, P., \& Calvo, P. Z. (2006). Antecedents of customer loyalty in residential energy markets: Service quality, satisfaction, trust and switching costs. The Service Industries Journal, 26(6), 633-650.

Iglesias, M. P., \& Guillén, M. J. Y. (2004). Perceived quality and price: their impact on the satisfaction of restaurant customers. International Journal of Contemporary hospitality management, 16 (6), 373-379.

Jamal, A., \& Al-Marri, M. (2007). Exploring the effect of self-image congruence and brand preference on satisfaction: the role of expertise. Journal of Marketing Management, 23(7-8), 613-629.

Johnston, R. (1995). The determinants of service quality: satisfiers and dissatisfiers. International journal of service industry management, 6(5), 53-71.

Johnston, R., \& Lyth, D. (1991). Implementing the integration of customer expectations and operational capability. Service quality: Multidisciplinary and multinational perspectives, 179190.

Juneja, D., Ahmad, S., \& Kumar, S. (2011). Adaptability of total quality management to service sector. International Journal of Computer Science \& Management Studies, 11(2), 93-98.

Jusoh, A., Omain, S. Z., Majid, A. A., Som, M. H., \& Shamsuddin, A. S. (2004). Service quality in higher education: Management students' perspective. Unpublished Project Report. Skudai, Johor: UTM [Technology University of Malaysia].

Kandampully, J. (1998). Service quality to service loyalty: A relationship which goes beyond customer services. Total quality management, 9(6), 431-443.

Karatepe, O. M. (2011). Service quality, customer satisfaction and loyalty: the moderating role of gender. Journal of Business Economics and Management, 12(2), 278-300.

Kotler, P. (2000). Marketing Management. 10th ed., New Jersey, Prentice-Hall.

LaBarbera, P. A., \& Mazursky, D. (1983). A longitudinal assessment of consumer satisfaction/dissatisfaction: the dynamic aspect of the cognitive process. Journal of marketing research, 20(4), 393-404.

Ladhari, R., Souiden, N., \& Ladhari, I. (2011). Determinants of loyalty and recommendation: The role of perceived service quality, emotional satisfaction and image. Journal of Financial Services Marketing, 16(2), 111-124.

Ladhari, R., Souiden, N., \& Ladhari, I. (2011). Determinants of loyalty and recommendation: The role of perceived service quality, emotional satisfaction and image. Journal of Financial Services Marketing, 16(2), 111-124.

Lehtinen, U., \& Lehtinen, J. R. (1982). Service quality: a study of quality dimensions. Service Management Institute.

Lovelock, C. and Wirtz, J. (2007), “Service Management: People, Technology, Strategy" (7th ed.), Person Prentice Hall, USA HF5415.13.L588

Luo, X., Wieseke, J., \& Homburg, C. (2012). Incentivizing CEOs to build customer-and employee-firm relations for higher customer satisfaction and firm value.Journal of the Academy of Marketing Science, 40(6), 745-758.

Mohamed, A. I. (2014). Service Quality Provided by Higher Education Institutions in Somalia and Its Impact on Student Satisfaction. Context, 6(11).

Muyeed, M. A. (2012). Customer perception on service quality in retail banking in developing countries-a case study. International Journal of Marketing Studies, 4(1), 116.

Oly Ndubisi, N. (2006). Effect of gender on customer loyalty: a relationship marketing approach. Marketing intelligence \& planning, 24(1), 48-61.

Oly Ndubisi, N., \& Kok Wah, C. (2005). Factorial and discriminant analyses of the underpinnings of relationship marketing and customer satisfaction. International Journal of Bank Marketing, 23(7), 542-557. 
Osman, A. R., \& Saputra, R. S. (2019). A pragmatic model of student satisfaction: a viewpoint of private higher education. Quality Assurance in Education.

Parasuraman, A., Zeithaml, V. A., \& Berry, L. L. (1985). A conceptual model of service quality and its implications for future research. Journal of marketing, 49(4), 41-50.

Parasuraman, A., Zeithaml, V. A., \& Berry, L. L. (1988). Servqual: A multiple-item scale for measuring consumer perc. Journal of retailing, 64(1), 12.

Pedraja Iglesias, M., \& Jesus Yagüe Guillén, M. (2004). Perceived quality and price: their impact on the satisfaction of restaurant customers. International Journal of Contemporary Hospitality Management, 16(6), 373-379.

Poturak, M. (2014). Private universities service quality and students satisfaction. Global Business and Economics Research Journal, 3(2), 33-49.

Ravald, A., \& Grönroos, C. (1996). The value concept and relationship marketing. European journal of marketing, 30(2), 19-30.

Robinot, E., \& Giannelloni, J. L. (2010). Do hotels' "green" attributes contribute to customer satisfaction?. Journal of Services Marketing, 24(2), 157-169.

Sasser, W. E., Olsen, R. P., \& Wyckoff, D. D. (1978). Management of service operations: Text, cases, and readings. Allyn \& Bacon.

Sultan, P., \& Yin Wong, H. (2010). Service quality in higher education-a review and research agenda. International Journal of Quality and Service Sciences, 2(2), 259-272.

Swar, B., \& Sahoo, P. (2012). Determinants of Effective Service Delivery: A Study of Selected Public, Private and Foreign Sector Banks in Odisha. Business Perspectives and Research, 1(1), 47-60.

Tiedemann, J. (2009). News from OPUS-A collection of multilingual parallel corpora with tools and interfaces. In Recent advances in natural language processing (Vol. 5, pp. 237-248).

Torlak, N. G., Demir, A., \& Budur, T. (2019). Impact of operations management strategies on customer satisfaction and behavioral intentions at café-restaurants. International Journal of Productivity and Performance Management.

Vazifehdust, H., Shahnavazi, A., Jourshari, M. R. T., \& Sharifi, F. S. (2012). Investigation critical success factors of customer relationship management implementation. World Applied Sciences Journal, 18(8), 1052-1064.

Voss, R., Gruber, T., \& Szmigin, I. (2007). Service quality in higher education: The role of student expectations. Journal of Business Research, 60(9), 949-959.

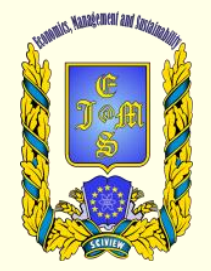

(c) 2016-2019, Economics, Management and Sustainability. All rights reserved.

This open access article is distributed under a Creative Commons Attribution (CC-BY) 4.0 license.

You are free to:

Share - copy and redistribute the material in any medium or format Adapt - remix, transform, and build upon the material for any

purpose, even commercially.

The licensor cannot revoke these freedoms as long as you follow the license terms.

Under the following terms:

Attribution - You must give appropriate credit, provide a link to the license, and indicate if changes were made.

You may do so in any reasonable manner, but not in any way that suggests the licensor endorses you or your use.

No additional restrictions

You may not apply legal terms or technological measures that legally restrict others from doing anything the license permits.

Economics, Management and Sustainability (ISSN: 2520-6303) is published by Scientific Publishing House "CSR",

Poland, EU and Scientific Publishing House "SciView", Poland

Publishing with JEMS ensures:

- Immediate, universal access to your article on publication

- High visibility and discoverability via the JEMS website

- Rapid publication

- Guaranteed legacy preservation of your article

- Discounts and waivers for authors in developing regions

Submit your manuscript to a JEMS at http://jems.sciview.net or submit.jems@sciview.net

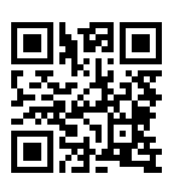

